\title{
Comments
}

\section{LABOR'S ANTITRUST EXEMPTION}

In United Mine Workers v. Pennington ${ }^{1}$ and Local 189, Amalgamated Meat Cutters v. Jewel Tea Co., ${ }^{2}$ the United States Supreme Court again undertook the delicate task of defining the antitrust exemption granted labor unions by section six of the Clayton Act. ${ }^{3}$ The Court construed the Labor Management Relations Act (LMRA) ${ }^{4}$ together with the Sherman Antitrust Act $^{5}$ to reconcile the competing policies which underlie the two sets of legislation. ${ }^{6}$ This Comment will examine the method of dual construction of the labor and antitrust laws, its application in Pennington and Jewel Tea, and the three problems which Pennington and Jewel Tea leave unresolved. Section II will discuss the kind of proof required to estabhish a prima facie case of a union-enployer conspiracy under the Pennington doctrime. Section III will set forth the kinds of union activities which fail to meet the Jewel Tea test for union antitrust immunity. Section IV will examine the problem of what kind of non-exempt union conduct will constitute substantive antitrust violations.

The recent history of labor's antitrust exemption begins with United States v. Hutcheson. ${ }^{7}$ This case arose shortly after the enactment of the first major federal labor legislation, the Norris-LaGuardia Act ${ }^{8}$ and the Wagner Act. ${ }^{9}$ In Hutcheson Justice Frankfurter, writing for a majority of the Court, first enunciated the dual construction doctrine. He stated that the passage of the Norris-LaGuardia Act did not annend the antitrust laws; rather Congress intended to reassert an original purpose of the Clayton Act-that of freeing most labor union activity froni antitrust liability. ${ }^{10}$

1381 U.S. 657 (1965).

2381 U.S. 676 (1965).

338 Stat. 731 (1914), 15 U.S.C. § 17 (1964).

461 Stat. 136 (1947), as amended, 29 U.S.C. $\$ \$ 141-87$ (1964).

ธ 26 Stat. 209 (1890), as amended, 15 U.S.C. $\$ \S 1-7$ (1964).

6 The basic policy of the antitrust laws is to eliminate undue restraints upon competition; the basic policy of federal labor legislation is the promotion of industrial peace and the equalization of bargaiming power between business and labor. For an excellent discussion of the unavoidability of the conflict between these two policies see Winter, Collective Bargaining and Competition: The Application of Antitrust Standards to Union Activities, 73 YarE L.J. 14, 16-30 (1963).

7312 U.S. 219 (1941).

847 Stat. 70 (1932), as amended, 29 U.S.C. $\S \S 101-15$ (1964).

9 National Labor Relations Act (Wagner Act), 49 Stat. 449 (1935), as amended and reenacted by the Labor Management Relations Act (Taft-Hartley Act), 61 Stat. 136 (1947), as amended, 29 U.S.C. $\$ \$ 141-87$ (1964).

10312 U.S. at 236 . In a line of Supreme Court cases which liad previously interpreted 
The Norris-LaGuardia Act freed certain union conduct from the threat of injunctions. The Court held that the same conduct was also exempt from the antitrust laws, so long as the "union acts in its own self interest and does not combine with non-labor groups."11 Since section four of the Norris-LaGuardia Act ${ }^{12}$ hiterally made non-enjoinable all peaceful labor union conduct undertaken in the course of a labor dispute, labor unions were thus granted what appeared to be a blanket exemption from the antitrust laws.

However, Justice Frankfurter's admonishment that labor unions must refrain from combining with non-labor groups was read into the NorrisLaGuardia Act for cases involving alleged union antitrust violations. In Allen-Bradley Co. v. Local 3, Int'l Bhd. of Elec. Workers, ${ }^{13}$ the Court ruled that a labor union must meet this requirement before its conduct could come within the protection of section four of the Norris-LaGuardia Act. In Allen-Bradley the Court held that peaceful union strikes and boycotts undertaken in conibmation with a group of employers as part of a plan to eliminate all price and market competition in the unionized market area were not within the protection of the Norris-LaGuardia Act. $^{14}$ Therefore, they were not exempt from the antitrust laws. ${ }^{15}$

Combining the Hutcheson and Allen-Bradley doctrines, the scope of labor's antitrust exemption at this time was that all union activity inust be undertaken independent from any non-labor group and must be nonenjoinable under the Norris-LaGuardia Act. ${ }^{16}$ The enactment of the

$\$ 6$ of the Clayton Act, the Court consistently ruled that \& 6 of the Clayton Act afforded no protection to certain activities such as secondary boycotts and union violence. See Bedford Cut Stone Co. v. Journeymen Stone Cutters Ass'n, 274 U.S. 37 (1927) (secondary boycott); United States v. Brims, 272 U.S. 549 (1926) (secondary boycott); Coronado Coal Co. v. UMW, 268 U.S. 295 (1925) (union violence); Duplex Printing Press Co. v. Deering, 254 U.S. 443 (1921) (secondary boycott). In this way the Clayton Act had been rendered almost useless as a protection against antitrust liability.

11312 U.S. at 232.

1247 Stat. 70 (1932), 29 U.S.C. $\& 101$ (1964).

13325 U.S. 797 (1945).

14 It is clear from the Court's decree, 325 U.S. at 812 , which granted an injunction against all union activity undertaken in combination with non-labor groups, that the factor of employer participation removed the union's activities from the protection of $\$ 4$ of the Norris-LaGuardia Act.

15325 U.S. at 810 . The facts in the Allen-Bradley case present an example of the abuses which might result if labor unions were given an unlimited antitrust exemption. The union negotiated an agreement with electrical contractors in New York City whereby the contractors were bound to buy electrical equipment only from manufacturers in New York City who had signed union contracts. The overall plan was policed by the union; non-union contractors and manufacturers were struck, boycotted and otherwise excluded from the New York City market: Eventually the plan beame so successful that extensive price fixing and bid rigging schemes were added; these in turn made possible much higher prices and wages.

16 The scope of labor's antitrust exemption at this time is made abundantly clear by an examination of the case of Hunt v. Crumbach, 325 U.S. 821 (1945), which was decided the 
Taft-Hartley amendments to the Wagner Act in $1947^{17}$ clouded the law. An affirmative duty was placed on the unions to bargain about wages, hours, and working conditions, ${ }^{18}$ and specific types of union conduct, such as secondary boycotts and jurisdictional strikes were declared to be unfair labor practices. ${ }^{19}$

During the twenty year period following Allen-Bradley and prior to Pennington and Jewel Tea, the Court had no occasion to pass upon the effect of the Taft-Hartley and 1959 amendments ${ }^{20}$ on the scope of labor's antitrust exemption. Two principal questions concerning the scope of this exemption were outstanding on the eve of Pennington and Jevel Tea. First, did the process of construing the labor laws together with the antitrust laws require labor's antitrust exemption to be defined in terms of conduct protected by the LMRA, rather than defined in terms of conduct protected by the older Norris-LaGuardia Act? This question was answered in Jevel Tea. Second, would the Court follow Allen-Bradley and deny antitrust immunity to all union conduct which was undertaken in combination with non-labor groups? The Court met this question in Pennington.

\section{Pennington AND Jewel Tea}

In Pennington, trustees of the United Mine Workers' Welfare Fund commenced an action agamst the owners of Phillips Brothers Coal Company to recover royalty payments claimed to be due under a collective bargaining agreement. The company cross-claimed under the Sherman Act against the UMW for damages resulting from an alleged conspiracy

same day as the Allen-Bradley case. In the Hunt case, the union had refused to negotiate a contract with an employer and had driven him out of busimess. The sole motive for the union's refusal to negotiate was its desire to satisfy a grudge agamst the employer. The Court held that even though the union's purpose in refusing to negotiate was reprehensible, its actions were completely exempt from the antitrust laws because they were undertalen alone and were non-enjoinable. The Court rejected the view that only union activities designed to effect a legitimate union aim would be granted antitrust immunity. This interpretation had been expressed in dictum by the Court shortly before the Hutcheson decision. See Apex Hosiery Co. v. Leader, 310 U.S. 469, 503 (1940).

1761 Stat. 136 (1947), as ainended, 29 U.S.C. $\$$ 141-87 (1964).

1861 Stat. 141, 142 (1947), 29 U.S.C. $\$ 158$ (b) (3), (d) (1964).

1961 Stat. 141 (1947) as amended, 29 V.S.C. \& $158(\mathrm{~b})$ (4) (B) (1964) (outlawing secondary boycott); 61 Stat. 142 (1947), 29 U.S.C. \& 158(b)(4)(D) (1964) (outlawing jurisdictional strikes).

20 The Labor Manageinent Reporting and Disclosure Act (Landrum-Grifin Act), 73 Stat. 543 (1959), 29 U.S.C. $\$ \$ 153-87$ (1964). Section 704 of the act, 73 Stat. 542-44 (1959), 29 U.S.C. $§ 158$ (e) (1964), outlawed the hot cargo clause. A hot cargo clause is a provision inserted in a collective hargaining agrecment with one employer which allows his employees to refuse to handle the goods of another employer with whom a union has a dispute. 
between the union and certain large coal producers to monopolize the coal industry and stabilize wage rates at a high level. The company alleged that the UMW agreed with the large coal producers that the UMW would demand from all coal producers a uniformly high wage which could only be met by large coal producers able to mechanize. ${ }^{21}$ All this was done allegedly to solve the coal industry's traditional problem of overproduction and low wages. The company further alleged that a campaign of strikes was instituted against the small coal producers. These small producers were unable to pay the high wage rate and were driven out of business. The jury returned a verdict for the company, awarding treble daniages. The union appealed, claiming that the demands which it made upon the company were entirely exempt from the antitrust laws. The basis of the union's claim was that the demands concerned only wages, hours and working conditions-mandatory subjects of collective bargaining under the LMRA. The court of appeals affirmed, since adequate evidence liad been presented to support the district court's finding that the union demands had been made in combination with the large coal producers. ${ }^{22}$ The Supreme Court, therefore, was presented squarely with the question whether union conduct otherwise permissible under the labor laws-mandatory bargaiming about wages, hours and working conditions-could be denied antitrust immunity for the sole reason that such conduct was undertaken in combination with non-labor groups. Justice White, dehivering the opinion of the Court, left no doubt on this issue. ${ }^{23}$

Unions, he stated, do have the right to make wage agreements with single employers or multi-employer bargaining units. They may demand similar agreements from other employers, for the elinination of competition based on differing labor standards is a legitimate objective of any labor union. ${ }^{24}$ However, the Court held that "a union forfeits its exemption from the antitrust laws when it is clearly slown that it has agreed with one set of employers to impose a certain wage scale on other

21 Prior to 1950, the UMW had attempted to meet the problem of overproduction by opposing mechanization and by reducing the miners' working hours. One of the methods by which the union controlled the miners' working hours was the negotiation of provisions in collective bargaining agreements which allowed the UMW to suspend unilaterally all coal production. In Penello v. UMW, 88 F. Supp. 935, 938-42 (D.D.C. 1950), the UMW's msistence on including these provisions in a collective bargaining dispute was held to be an unfair labor practice.

For a history of UMW policies see Baratz, ThE UNION AND THE COAL INDUSTRY 62-74 (1955).

\footnotetext{
22325 F.2d 804 (6th Cir. 1963).

23381 U.S. 657 (1965).

24 Id. at 665-66.
} 
bargaining units."25 The Court concluded that the union's activities would be subject to the antitrust laws if on remand the district court should find an agreement between the UMW and the large coal producers to secure uniform labor standards throughout the industry. ${ }^{26}$

The Court did not rule that antitrust liability resulted simply because the union's conduct was non-exempt. The question of ultimate liability under the antitrust laws was not reached in the majority opinion because the case was reversed on the narrow ground of erroneous instruction by the district court judge. ${ }^{27}$

Unlike the Pennington case, the Jewel Tea case ${ }^{28}$ reached the Court stripped of any claim that the defendant union's demands on the complaining company were nıade in combination with a non-labor group. Consequently the Court was faced with the task of defining the scope of labor's antitrust exemption with regard to union conduct not undertaken in combination with a non-labor group. The Jewel Tea Company claimed in the district court that the union had violated the Sherman Act by compelling the company under threat of strike to sign a collective bargaining agreement which prohibited the company from selling meat between the hours of 6:00 p.m. and 9:00 a.n.

The coinpany's theory was that the union had conspired with a trade association representing about 1,000 independent nerchants to eliminate the competition offered by the company's self-service markets. The independent neerchants were subject to a collective bargaining agreement which restricted butchers' work hours to the 9:00 a.m. to 6:00 p.m. period. Unlike the independent merchants, Jewel Tea's self-service markets could sell meat at night without butchers.

The district judge ruled that no evidence of a conspiracy between the union and the association had been presented. ${ }^{20}$ The judge found that the union's action had been undertaken on its own. He concluded that the company could not in fact market neat at night without either requiring the services of butchers during those hours or requiring other unskilled employees to perform the butchers' tasks. Consequently, the restriction

25 Id. at 665 .

26 Id. at 669 .

$27 I d$. at 670 . The district judge instructed the jury that alleged joint approaches by the UMW and the large coal producers to the Secretary of Labor in an attempt to establish under the Walsh-Healey Act, 49 Stat. 2036 (1936), as amended, 41 U.S.C. $\$ \$ 35-45$ (1964), a minimum wage for contractors selling coal to the TVA could form part of the illegal conspiracy and could be a basis for damages. This instruction, the Court ruled, was incorrect under Eastern R.R. President's Conference v. Noerr Motor Freight, Inc. 365 U.S. 127 (1961), which held that all acts undertaken to influence public officials in the proper performance of their duties are entirely exempt from the antitrust laws.

28381 U.S. 676 (1965).

29215 F. Supp. 839, 848 (N.D. Ill. 1963). 
concerned hours of employment, a mandatory subject of collective bargaining. On these grounds the court held that the union's conduct fell squarely within labor's antitrust exemption. The case was reversed by the court of appeals in an opinion which left intact the district court's finding that apart from the fact of the existence of a collective bargaiming agreement between the union and the association, no evidence of a conspiracy between the union and the association had been presented. ${ }^{30}$ The Supreme Court granted certiorari to review whether the marketing hour restrictions, inposed by the union in its own interest and not on the basis of an agreement with the association, were exempt from the antitrust laws. ${ }^{31}$

Justice White, again announcing the judgment of the Court, ${ }^{32}$ held that union activity not undertaken in combination with non-labor groups was exeinpt froin the antitrust laws only if it constituted mandatory union bargaining about the wages, hours and working conditions of the einployees within the bargaining unit. ${ }^{33} \mathrm{He}$ stated that if the company could not market ineat at night without affecting the daytime hours or the assigned tasks of the union butchers, the marketing hour restriction would constitute a legitimate concern of those union members within the bargaining unit. ${ }^{34}$ If this were the case, the restriction would be exempt from the antitrust laws. ${ }^{35}$

On the other hand, Justice White continued, if the company could narket ineat at night without affecting the hours or workload of the union butchers within the bargaining unit, the marketing hour restriction would not constitute union bargaining about wages, hours or working conditions and, therefore, the restriction would not be granted antitrust immunity. ${ }^{30}$ To resolve the factual question, White relied upon the district court. He was satisfied that its finding that night marketing would affect the butchers' hours was not clearly erroneous. ${ }^{37}$

Justice Douglas wrote a separate opinion, joined by Justices

30331 F.2d 547, 551 (7th Cir. 1964).

31379 U.S. 812 (1965).

32 There was no opinion of the Court. Justice White announced the judgment of the Court in an opinion which Chief Justice Warren and Justice Brennan joined. Justice Goldberg, joined by Justices Harlan and Stewart, concurred in the reversal of the court of appeals decision but dissented from Justice White's reasoning concerning the scope of labor's antitrust exemption. See notes $43-45$ infra and accompanying text. The dissenting opimion of Justice Douglas, in which Justices Black and Clark joined, agreed with the opinion of Justice White as to the broad questions of law regarding labor's antitrust exemption but dissented from the reversal. See test accompanying notes 38-40 infra.

33381 U.S. at 691.

34 Id. at 692-93.

35 Id. at 692 .

36 Id. at 692-93.

37 Id. at 697 . 
Black and Clark. He agreed with Justice White's approach of construing the antitrust laws in conjunction with the LMRA to exempt from the former only union bargaining about the wages, hours and working conditions; but he dissented from the majority result on two grounds. First, consistent with his separate opinion in Pennington, ${ }^{38}$ Douglas contended that ample evidence had been introduced on the question of a conspiracy between the union and the association. ${ }^{39}$ Second, Douglas rejected as not supported by the evidence the district court's finding that the marketing hour restriction was necessary to protect the butchers' working hours. ${ }^{40}$

In both Pennington and Jerel Tea a majority of the court-Justices White, Brennan, Douglas, Black, and Clark, and Chief Justice Warrenset forth quite clearly the general categories of union conduct which are excluded from labor's antitrust exemption. In Pennington the Court excluded all union activity undertaken in combination with einployers. In Jewel Tea they excluded union activity which does not constitute bargaining about the wages, hours and working conditions of union members within the bargaining unit. The scope of labor's antitrust exemption as it stood under the Hutcheson ${ }^{41}$ and Allen-Bradley ${ }^{42}$ decisions experienced a major change. Under Pennington and Jewel Tea it is clear that the LMRA, and not the Norris-LaGuardia Act, defines the limit of labor's antitrust exemption.

Justice Goldberg, joined by Justices Harlan and Stewart, in a single opinion, concurred in the results of both Pennington and Jezel Tea, but strongly dissented from the majority's conclusions on the broad questions concerning the scope of labor's antitrust exemption. The doctrines established in the Pennington and Jewel Tea decisions, Goldberg contended, were further examples of judicial interference with legitimate collective bargaining. ${ }^{43}$ In his opinion the courts are ill-equipped to judge the motives or intent of labor union bargaining and policies. The enactment of a comprehensive body of labor legislation evidenced an intent on the part of Congress to foreclose all inquiry into union bargaining about wages, hours and working conditions. Accordingly, he concluded that simply because the union undertakes such activities in combination with a non-labor group, it should not be denied the protection of the antitrust exemption. ${ }^{44}$ In addition, Goldberg disagreed with the view that a

38381 U.S. at 672 . See notes $49-50$ infra and accompanying text.

39381 U.S. at 736-37. The problem of the correct rule of evidence necessary to establish a umion-employer conspiracy will be discussed in section $I I$ of this Comment. See text at note 46 infra.

40381 U.S. at 737-38.

41312 U.S. 219 (1941).

42325 U.S. 797 (1945).

43381 U.S. at 700 .

44 Id. at 707-710. 
labor union's immunity should depend upon whether or not its activity constituted bargaining about the wages, hours and working conditions of union members within the bargaining unit. The welfare of the entire union membership, rather than only the welfare of the members within the immediate bargaining unit, is a legitimate union concern. All union activities, even those designed solely to hamper the employer's ability to compete with other employers without benefiting the bargaining unit enIployees, sliould be exempt from the antitrust laws so long as they do not include demands that the employer enter into price fixing or market control agreements with other employers. ${ }^{45}$ The Goldberg faction thus favored a much broader antitrust exemption than a majority of the Court outhined in Pennington and Jewel Tea.

\section{II} PROOF OF UNION-EMPIOYER CONSPIRACIES

The Pennington doctrine, although clear in the abstract, may prove to be extremely difficult to apply. Formulating the doctrine is relatively simple. All union demands made in combination with an employer or employer group are not exempt from the antitrust laws. Deciding whether the particular union demands under attack were made pursuant to an agreement with an employer or employer group is a different problem. The question of what constitutes a prima facie case of non-exemption under the Pennington doctrine-that is, what is evidence sufficient for the trier of fact to infer that a union-employer combination existswill most likely prove to be the most litigated issue in cases tried under the Pennington theory.

The evidentiary rules regarding the establishment of conspiracies in restraint of trade have been articulated by the courts in reference to conspiracies between competing business enterprises. A primary evidentiary rule evolved in the context of establishing business conspiracies is that all business behavior is admissible as circumstantial evidence from which the trier of fact may infer an illegal agreement. ${ }^{46}$ Parallel conduct on the part of business enterprises lias constituted the bulk of such evidence. The courts have developed rules which control the proper weight to be given to parallel conduct of business enterprises as proof of a conspiracy.77 A major evidentiary problem of the union-employer conspiracy case is how the evidentiary rules developed in the business

45 Id. at 727. Justice Goldberg argued that the union in Jewel Tea had a legitimate interest in the small meat markets' competitive survival: ensuring total union einployment. This view rejected the majority's holding that to be exempt the union activities must benefit the wages, hours or working conditions of the union members within the bargaining unit.

46 See note 55 infra and accompanying text.

47 See notes 56-57 infra and accompanying text. 
context should be applied to the union-employer situation. To reach a fair result courts must consider that a union's role in a private enterprise economy is quite different from that of a business enterprise.

Unions necessarily exist for the purpose of entering into collective bargaining agreements. Under the LMRA they have a duty to bargain about wages, hours and working conditions. ${ }^{48}$ There is always ample opportunity for the union to enter into an illegal conspiracy with an employer. In addition, any union policy will always benefit the competitive position of one group of employers in a particular industry visà-vis other employers in that industry. Employers such as the large coal producers in Pennington, who are able to mechanize, will benefit from a union policy designed to promote high wages in return for reduced total union employment. Conversely, small employers, who are unable to undertake large capital expenditures for mechanization, will benefit from a union policy which attempts to increase total union employment at the possible cost of lower wage rates.

If the courts apply a rule of evidence under which a union's demands of one employer are found to be made in conspiracy with another employer simply because (1) the union had previously entered into a collective bargaining agreement with the other employer, and (2) the union's demands on both employers tended to harm the competitive position of the second employer, a conspiracy could be formd in a very large number of normal collective bargaining situations. The six justices who concurred in aunouncing the Pennington doctrime split evenly on the question of whether such a freewheeling rule should be applied.

Justices Douglas, Black, and Clark favored such a rule. Justice Douglas implied in his opinion in Pennington that the collective bargaining agreement between the UMW and the large coal producers, while containing no express agreement regarding demands to be made upon the small producers, was in itself sufficient evidence that the UMW had agreed with the large producers to inpose the same conditions upon the small producers. ${ }^{49} \mathrm{He}$ felt that this conclusion was dictated by the rule of conscious parallelism which is applied in the business enterprise cases. ${ }^{50}$ Similarly, in his dissenting opinion in Jevel Tea, in which he was again joimed by Justices Black and Clark, he would have overruled the district court's finding that no evidence had been introduced to indicate the existence of an agreement between the union and the association to impose the marketing hour restriction on the Jewel Tea Company. He would have allowed the district court on remand to infer sucls

4861 Stat. 141, 142 (1947), 29 U.S.C. § 158(b) (3), (d) (1964).

48381 U.S. at 673.

ธo Ibid. 
an agreement solely from the existence of the ordinary collective bargaining agreement between the union and the association. ${ }^{51}$

Justice White's opinions im both Pennington and Jevel Tea, in which Chief Justice Warren and Justice Brennan jomed, rejected this position. In Pennington Justice White made it quite clear that a union may make wage agreements with nulti-employer bargaining groups and attempt to impose the same terms on other employers without fear of running afoul of the antitrust laws. In his opinion such conduct alone would not be sufficient evidence of a conspiracy..$^{52}$ Consistent with this approach, he upheld the district court's disnnissal in Jezel Tea of the union-employer conspiracy charge..$^{53}$

Justice Goldberg did not announce what he considered to be sufficient evidence to establish a prima facie case of non-exemption under the Pennington doctrine. However, considering the disfavor with which he and Justices Harlan and Stewart viewed the Pennington doctrine, ${ }^{54}$ it would appear safe to assume that Justices Harlan and Stewart would go at least as far as Justices White, and Brennan and Chief Justice Warren in requiring substantial evidence of a umion-employer conspiracy. This would place a majority of the Court in favor of a strict evidentiary rule, whatever the views of Justice Fortas, who lias replaced Justice Goldberg on the Court.

The rejection of Justice Douglas's position appears to be justified. Acceptance of that position would expose almost all collective bargaining to possible antitrust hability, since any union policy will harm some entployers' competitive positions in an industry. In addition, the conscious parallelisn doctrme as it has developed in the business cases also justifies rejection of the Douglas evidentiary rule.

In the business context, busmess behavior is admissible as circunstantial evidence from which the trier of fact nay infer an illegal agreenient. ${ }^{55}$ This rule of circumstantial evidence, as articulated by the Supreme Court and refined by the courts of appeals, has moved in the direction of providing business enterprises with some margin of safety against courts which too readily allow the finder of fact to infer a conspiracy from parallel conduct. A number of cases in the circuit courts of appeals reveal that parallel conduct alone is not sufficient evidence of a conspiracy to withstand a motion to dismiss. ${ }^{56}$

51381 U.S. at 736-37. See text accompanying notes 39-40 supra.

52381 U.S. at 665 n.2.

63381 U.S. at 682 .

54 See text accompanying notes 43-45 supra. (1954).

65 E.g., Theatre Enterprises, Inc. v. Paramount Film Distrib. Corp., 346 U.S. 537, 540-41

56 Winchester Theatre Co. v. Paramount Film Distrib. Corp., 324 F.2d 652, 653 (1st Cir. 
Moreover, parallel conduct loses its probative force as evidence of a conspiracy between the acting parties if other evidence is offered to show the origin of the busmess policy and the legitimate business considerations which motivated its establishment. ${ }^{57}$ Once a business establishes these legitimate business considerations, then some additional proof of a conspiracy must be offered in evidence. A union should be treated no less fairly. If conspiracy is going to be the crux of a violation, then proof of a conspiracy sliould be clear. A complainant may establish the likelihood of a conspiracy by slowing parallel conduct. But once this likelihood has been effectively negated by slowing of a legitimate business purpose, the complainant should be required to establish a conspiracy by additional factors. Whenever a union can show that its demands on a particular employer concern only wages, lrours and working conditions, an inference of a conspiracy between the union and another employer should not be drawn. To establislı that union demands are not entitled to antitrust exemption, it should not be sufficient merely to establish a collective bargaining agreement between the union and another employer and an adverse impact on the complaining employer. The complamant slould be required to establisl other facts suggesting that the union's demands concerning wages, lours and working conditions were made pursuant to a conspiracy between the union and the other employer; if he does not, the evidence should not be sufficient to withstand a motion to dismiss the claim of non-exemption.

What other factors miglit be present in a case to suggest conspiracy? A few examples are suggested by the evidence introduced in the Pennington case. First, the complainant offered the express agreement of the large coal producers with the UMW not to sell or lease land to non-union producers nor to sell or buy coal from such producers. ${ }^{58}$ An agreement of this

1963); Independent Iron Works, Inc. v. United States Steel Corp., 322 F.2d 656, 661 (9th Cir.), cert. denied, 375 U.S. 922 (1963); Gold Fuel Serv. Inc. v. Esso Standard Oil Co., 306 F.2d 61, 64 (3d Cir.), cert. denied, 371 U.S. 951 (1962); Delaware Valley Marine Supply Co. v. American Tobacco Co., 297 F.2d 199, 202-03 (3d Cir. 1961), cert. denied, 369 U.S. 839 (1962) ; Brown v. Western Mass. Theatres, Inc., 288 F.2d 302, 305 (1st Cir. 1961).

${ }^{57}$ See Independent Iron Works, Inc. v. United States Steel Corp., 177 F. Supp. 743, 747 (N.D. Cal. 1959), aff'd, 322 F.2d 656 (9th Cir.), cert. denied, 375 U.S. 922 (1963); United States v. Twentieth Century-Fox Film Corp., 137 F. Supp. 78, 85 (S.D. Cal. 1956).

However, when other circumstances are present, such as the adoption of a policy in apparent contradiction of the defendant's best interests, then the inference of a conspiracy is permissible. See, e.g., Delaware Valley Marine Supply Co. v. American Tobacco Co., sttpra note 56; Milgram v. Loew's, Inc., 192 F.2d 579, 583 (3d Cir. 1951), cert. denied, 343 U.S. 929 (1952) ; Parsons v. Paraniount Film Distrib. Corp., 215 F. Supp. 153, 159 (D. Minn. 1963). But independent justification for the allegedly concerted conduct can always be used to rebut the inference of an agreement. National Comonatree to Study the ANtTrkust LAWS, U.S. ATTORNEY GENERAI, REPORT 39-40 (1955).

58381 U.S. at 660. 
kind could be additional evidence of a plan designed to harm those employers who are the objects of the agreement. It might well suggest that the union desires to hinder the complainant's ability to carry on its business, quite apart from the union's wage and hour policies.

Second, the district court in Pennington appeared to view the union's ownership of a substantial amount of stock in the large coal producers as evidence of union participation in the producers' activities to drive the small producers out of business. ${ }^{59}$ This rule may or may not be valid generally, ${ }^{60}$ but it suggests a factor which might increase the possibility that a conspiracy exists in a particular case. An additional factor in Pennington was actual union participation with the other employer in approaching government officials for purposes which tended to harn the complaining einployer. ${ }^{81}$ These exainples by no means exhaust all possibilities of additional factors. The evidentiary rules evolved by the courts should not be reduced to rigid categories but should remain flexible. ${ }^{62}$ One

59 Lewis v. Pennington, 1961 Trade Cas. 78125, 78128 (E.D. Tenn. 1961).

${ }^{60}$ The validity of such a rule may be doubtful in light of the fact that a union may have legitimate business reasons for the ownership of shares of stock in the coinpany with which it bargains. A desire on the part of the uunon to have a say in other than labor matters may constitute a valid business motive. Also, unions often have large funds which they must mvest and it would seem preferable for them to invest those funds in private enterprises rather than having to mvest only in other types of securities.

61381 U.S. at 660-61. Although approaching a governmental official in an attempt to influence his proper duties by lawful means could not form a basis for damages, see note 27 supra, such activities could be admitted as evidence tending to show the purpose and character of the other activities of the parties under scrutiny. 381 U.S. at 670 n.3.

62 The district court on remand of the case, Lewis v. Pennington, 257 F. Supp. 815 (E.D. Tenn. 1966), considered all of the evidence which had been introduced at the original trial and ruled that the conspiracy had not been proved by a preponderance of the evidence. Id. at 864. After an extensive examination of the facts, the district court determined that valid competitive considerations had dictated the prices charged by the large coal producers on the TVA spot market; that the leasing restriction, text accompanying note 58 sitpra, was explainable as a method by which the major producers were prevented from avoiding their obligations under the collective bargaining agreement; and that a protective wage provision, whereby the umion agreed to use its best efforts to obtain full compliance with the agreement from all parties signing it did not impose a duty upon the union beyond the bargaining unit. Id. at 862 .

One curious factor which might be noted in the district court's opmion on remand of Pentrington is wliat the court considered to be the proper rule of evidence with respect to proof of a conspiracy in restraint of trade between a union and a non-labor group. The district court stated that a union antitrust conspiracy must be proved by a margin greater then a mere preponderance the evidence. Id. at 826 . It did, however, protect itself against reversal on this issue by holding that the evidence met neither its rule nor the preponderence rule. Id. at 864 .

In the case of UMW v. Gibbs, 383 U.S. 715 (1966), the Supreme Court held that $\S 6$ of the Norris-LaGuardia Act (wlicli states that no association participating in a labor dispute shall be held liable for the unlawful acts of its individual neenbers or officers except upon clear proof of their actual authorization) requires something more than a mere preponderance of the evidence to prove authorization. The district court in Pennington relied on the 
rigid evidentiary rule, however, should be followed: normal umion bargaining about the wages, hours and working conditions of union members within the bargaining unit, and the inevitable economic consequences of demands made pursuant to such bargaining, should never be considered, in themselves, sufficient evidence of a union-employer conspiracy. Under this rule, if the union restricts its bargaining activities to demands concerning the mandatory subjects of collective bargaining in the LMRA its conduct would always come within labor's antitrust exemption.

\section{III}

\section{CONDUCT OUTSIDE THE PROTECTION}

\section{OF THE Jewel Tea DOCTRINE}

Prior to Jewel Tea, the Court defined the scope of labor's antitrust exemption in terms of the conduct which was made non-enjoinable under the Norris-LaGuardia Act. The Court in Jevel Tea apparently abandoned this approach when it failed to place any importance upon the NorrisLaGuardia Act. By placing its emphasis mstead upon the concept of the bargaiming unit and the mandatory subjects of collective bargaining under the LMRA, the Court narrowed the linits of the exemption to those activities protected by the LMRA.

In light of this narrowed immunity, certain kinds of union conduct may now fail to come within the scope of labor's antitrust exemption. The Court held in Jewel Tea that to be immune from the antitrust laws, union conduct must be ainied at protecting the wages, hours and working conditions of those union members within the bargaining unit. This position leads to the conclusion that all secondary union conduct may once again, as it was prior to Hutcheson, ${ }^{83}$ be subject to the antitrust laws. ${ }^{84}$ It does not, however, mean a complete return to the case authority prior to Hutcheson, for union conduct such as violence should not, under Jewel Tea, forfeit a union's exemption.

The Court in Jervel Tea reasoned that if the marketing hour restric-

Gibbs case as its only authority for the proper rule regarding proof of a union conspiracy in restraint of trade. Section 6 of the Norris-LaGuardia Act is not addressed in any way to the burden of proof which must be met in proving a union antitrust conspiracy; its provisions should have no bearing upon that issue.

The logical place to turn for the precedent with respect to this issue is the case of AllenBradley Co. v. Local 3, Int'l Bhd. of Elec. Workers, 325 U.S. 797 (1945), which is the only Supreme Court case which dealt with and upheld a finding of a umion-employer conspiracy in violation of the antitrust laws. In Allen-Bradley, the Court gave no indication that a unionemployer conspiracy must be proved by anything other than a normal preponderance of the evidence.

63312 U.S. 219 (1941).

64 See note 10 supra and accompanying text. 
tion were not intimately connected with the wages, hours and working conditions of the union employees within the bargaining unit, it would have been characterized as a provision designed to aid union members outside the bargaining unit by impeding the complainant's ability to carry on his busmess. ${ }^{65}$ This analysis is almost identical to that used by the NLRB and the courts in differentiating truly primary demands and agreements from those demands and agreements which are secondary in nature. ${ }^{68}$ The latter will violate either the secondary boycott or hot cargo provisions of the LMRA. ${ }^{67}$ If a union negotiates a contract in which the employer agrees to cease doing business with an "unfair" third party, such an agreement is a hot cargo agreement under section $8(\mathrm{e})$ of the LMRA and any strike or other coercive practice undertaken to enforce such a contract is a secondary boycott under section $8(\mathrm{~b})(4)$ (B) of the LMRA. ${ }^{89}$

However, contracts in which the employer agrees not to "contract out" work traditionally done by the union nembers within the bargaining unit have been held by the NLRB ${ }^{70}$ and by the courts ${ }^{71}$ to be primary. Such agreements are not considered within the proscription of section 8(e) of the LMRA because they have as their object the protection of wages, hours or working conditions of the bargaining unit employees. ${ }^{72}$ The najor distinction, therefore, in differentiating primary from secondary union activity is whether or not the demand or agreement has as its

${ }^{65} 381$ U.S. at 692-93.

${ }^{68}$ See NLRB v. Joint Council of Teamsters, 338 F.2d 23 (9th Cir. 1964); Meat \& Highway Drivers v. NLRB, 335 F.2d 709, 717 (D.C. Cir. 1964); Truck Drivers v. NLRB, 334 F.2d 539, 548 (D.C. Cir.), cert. denied, 379 U.S. 916 (1964); District No. 9, Int'l Ass'n of Machinists v. NLRB, 315 F.2d 33, 36-37 (D.C. Cir. 1962).

e7 Section 8(b)(4)(B) of the LMRA, 61 Stat. 141 (1947), as amended, 29 U.S.C. \& 158(b) (4) (B) (1964) outlaws the secondary boycott. Section 8(e) of the LMRA, 73 Stat. 542-44 (1959), 29 U.S.C. $\$ 158$ (e) (1964) outlaws the hot cargo clause.

88 The term "unfair" employer here denotes any employer with which the union has a dispute.

69 See Local 1976, United Bhd. of Carpenters v. NLRB, 357 U.S. 93 (1958); NLRB v. Milk Wagon Drivers' Umion, 335 F.2d 326 (7th Cir. 1964); Bakery Wagon Drivers' Union v. NLRB, 321 F.2d 353 (D.C. Cir. 1963).

70 Metropohtan Dist. Council of the United Bhd. of Carpenters, 149 N.L.R.B. 646, 657 (1964) ; Local 603, Milk Wagon Drivers, 145 N.L.R.B. 445 (1963).

71 E.g., Orange Belt Dist. Council of Painters v. NLRB, 328 F.2d 534, 538 (D.C. Cir. 1964) (holding that clause limiting subcontracting to employers who nraintain standards equal to those of the umion is a legitimate subcontracting clause, since it protects the bargaining unit standards); Todd Shipyards Corp. v. Industrial Union of Marme Workers, 232 F. Supp. 589 (E.D.N.Y. 1964).

72 The conclusions reached in these cases are supported by the case of Fiberboard Paper Prod. Corp. v. NLRB, 379 U.S. 203 (1964), in which the Supreme Court held that the subject of contracting out work previously done by union inembers within the bargaining unit is a mandatory subject of collective bargaining. See Comment, 54 CALrF. L. REv. 1749 (1966). 
objective the protection of those employees within the bargaining unit. ${ }^{78}$ This is precisely the test which the Court in Jewel Tea regarded as decisive in determining whether the marketing hour restriction was related to one of the mandatory subjects of collective bargaining and thus exempt from the antitrust laws. ${ }^{74}$

Hot cargo agreements and secondary boycotts constitute collective bargaming on a basis much broader than the bargaining unit. As construed by the courts and the NLRB, such demands cannot be justified as protection for union employees within the bargaining unit. By infusing the central concepts of the LMRA into the antitrust law exemption, the Court has apparently formulated a rule which will exclude all secondary union conduct from labor's antitrust exemption.

However, this reasoning would not seem to apply to union violence because union violence in the normal case will be undertaken to protect the wages, hours or working conditions of the union members within the bargaining unit. Therefore, the act of violence itself in such cases would probably come within the protection of the Jewel Tea doctrine.

\section{IV}

\section{SUBSTANTIVE UNION ANTITRUST VIOLATIONS}

To establish a umon's antitrust liability a complainant must establish both that the union's conduct was not exempt from the antitrust laws and that the union's conduct constituted a substantive antitrust violation. ${ }^{75}$

The Sherman Act sets forth a basic public policy directed against undue restraints on competition. ${ }^{78}$ Since the passage of the Clayton Act, it has been clear that employees need not compete among themselves, but may join together to raise labor standards by means of conduct which comes within labor's antitrust exemption. ${ }^{77}$ The proscriptions of the Sherman Act apply only to restraints on product markets. ${ }^{78}$ Union con-

73 See Cox, The Landrum-Grifin Amendments to the National Labor Relations Act, 44 Minv. L. Rev. 257, 273 (1959); Comment, 62 Micr. L. Rev. 1176, 1185-88 (1964). Both authors agree that this distinction is sound.

74381 U.S. at $689-90$. Deciding whether a given activity is related to wages, hours and working conditions is no easy matter. In Jewel Tea the Douglas faction felt that the marketing hour restriction was not related, while the White and Goldberg factions falt that it was. See notes 33-34 supra and accompanying text. (1965).

75 See Local 189, Amalgamated Meat Cutters v. Jewel Tea Co., 381 U.S. 676, 693

${ }^{76}$ See, e.g., Northern Pac. Ry. v. United States, 356 U.S. 1, 4 (1958).

77 United States v. Hutcheson, 312 U.S. 219, 236 (1941).

78 However, differentiating a labor market from product market, that is, deciding whether a group which has banded together in the form of a "union" is a labor group or a non-labor group can be quite diffcult. See Los Angeles Meat \& Provision Drivers v. United States, 371 U.S. 94 (1962); Columbia River Packers Ass'n v. Hinton, 315 U.S. 143 (1942); Milk Wagon 
duct which is not exempt from the antitrust laws and which also unduly restrains competition in product markets is in violation of the antitrust laws. ${ }^{79}$ Given non-exempt union conduct, a court faced with the question of whether an antitrust violation has occurred must first determine the nature of the competition restrained by the non-exempt union conduct. That is, whether the competition constitutes product market competition worthy of protection under the antitrust laws and whether the restraint is unreasonable. ${ }^{80}$

The most difficult problem in this area involves union conduct which is non-exempt for the sole reason that it is undertaken in combination with an employer. A clear example of such conduct occurs when a union enters into a collective bargaining agreement with an employer in which it expressly agrees to use its best efforts to obtain similar wage conditions from all other employers. ${ }^{81}$ The union then bargains with a second employer and demands that this uniform wage be granted. Arguably, the only kind of competition restrained by such a union demand is competition based on differing labor standards. This would be true if all employers are able to meet such a demand and remain in business. However, if some employers would be forced out of business by acceding to the demand, competition in the industry might be lessened. ${ }^{82}$ In the latter case, a nonexempt union activity might unreasonably restrain competition in the particular product market served by the industry and therefore be within the proscriptions of the antitrust laws. The opinion of the Court and the concurring opinion of Justice Douglas in Pennington offer little help in determining whether non-exempt union conduct which restrains only competition based on differing labor standards is within the proscription of the antitrust laws.

Under Justice White's opmion in Pennington, labor union conduct which restrains only competition based on differmg labor standards might cone within the proscription of the antitrust laws. Justice White made no reference to the type of competition which the alleged campaign of strikes restrained. However, the opinion of Justice Douglas, in which two

Drivers' Union v. Lake Valley Farn Prod., Inc., 311 U.S. 91 (1940). An excellent discussion of this problem is contained in Kirkpatrick, Crossroads of Antitrust and Union Power, 34 GEO. WASH. L. REv. 288, 307-313 (1965).

79 Allen-Bradley Co. v. Local 3, Int'l Bnd. of Elec. Workers, 325 U.S. 797 (1945).

80 Althouch $\$ 1$ of the Sherman Act is absolute on its face, the Supreme Court has read into the act a rule of reason to limit its coverage to restramts which are unreasonable. E.g., Standard Oil Co. v. United States, 221 U.S. 1 (1911); United States v. American Tobacco Co., 221 U.S. 106 (1911).

81 See text acconpanying notes 23-25 supra.

82 However, reduction of the total number of employers in an industry will not necessarily lessen competition. The remaining employers might maintain competition in the industry at the same level. 
other justices concurred, casts doubt on the proposition that a union's attempt in combination with one employer to obtain a uniform wage from another employer is sufficient to constitute an antitrust violation. Douglas stated that the union's conduct in Pennington should constitute an antitrust violation only if undertaken for the purpose of forcing the complainant out of business. ${ }^{83}$ On remand the district court adopted the Douglas approach requiring a predatory intent on the part of the umion as a necessary element of a union antitrust violation. ${ }^{84}$ This implies that the union must intend to restrain aspects of competition besides those based on differing labor standards. Whether the Court will require a predatory purpose on the part of the union beyond the purpose of stabilizing labor standards and eliminating competition based on such standards is at best conjectural. Pennington was himited to the question of union immunity from the antitrust laws and did not consider the question of the elements necessary for a substantive union antitrust violation.

Union conduct which is non-exempt under the Jewel Tea doctrinethat is, conduct which restricts the employer's ability to compete witlout affecting the wages, lours or working conditions of the employees within the bargaining unit--presents very little difficulty with regard to the kind of competition which it restrains. Conpetition restrained by sucls conduct by definition restricts the employer's ability to compete in fields other than labor standards. Therefore, even if a predatory purpose is required to make the conduct illegal, such a purpose would probably be easy to establish in a case of this type.

Aside from the question of the nature of the competition which the union may intend to restrict by non-exempt conduct, there still remains the final requirement that the restraint itself must be unreasonable. If in Jewel Tea, for example, the marketing hour restriction had been found to have no connection with the wages, hours and working conditions of union employees, the Court might still have determined that the restriction was reasonable and therefore not in violation of the antitrust laws. The question of reasonableness will most likely be based primarily upon business case precedents. ${ }^{85}$ The reasonableness of a particular kind of restraint, such as a marketing hour restriction, will therefore be judged in

83381 U.S. at $672-73$.

84257 F. Supp. at 829.

85 Indeed, the Court in Jewel Tea, in discussing the reasonableness of the marketing hour restriction, referred only to business case precedent. 381 U.S. at 693 n.6. This appears to be the correct approach. Business cases will provide the great bulk of precedent with respect to this issue. Further, what is and what is not permissable union activity from a labor policy standpoint will already have been taken into account in the immunity analysis, and, therefore, once immunity is denied antitrust policy should control the analysis of the substantive antitrust issues. 
light of the facts of the case and of the criteria set down in the prior business cases involving similar restrictions. ${ }^{86}$

\section{CONCLUSTON}

The Supreine Court attempted in Pennington and Jewel Tea to resolve the conflict between the antitrust laws and the federal labor laws. The Court construed the two sets of legislation together to define the scope of labor's antitrust exemption.

The two decisions set forth certain types of conduct which will not be granted antitrust immunity. Under the Pennington doctrine any union conduct undertaken in combination with non-labor groups will be subject to the antitrust laws. Because unions exist for the purpose of bargaining for their members' wages, hours and working conditions, an even-handed and fair administration of the antitrust laws require that such unionemployer combinations be proved by facts other than the normal economic impact which these demands have upon certain employers. The Supreme Court in Jewel Tea held that union conduct which caunot be characterized as union bargaining about wages, hours and working conditions of those union inembers within the immediate bargaining unit will not be exempt from the antitrust laws. Because secondary union conduct by definition is designed to aid employees outside the bargaining unit, all secondary union activity should also be included in this non-exempt category.

The courts have not yet determined what kind of union conduct will constitute a substantive antitrust violation. The Supreme Court did not face this question in either Pennington or Jewel Tea. Both cases were

86 Justice Brandeis in articulating the rule of reason stated that, in order to determine the reasonableness of a restraint, the "court must ordinarily consider the facts peculiar to the business to which the restraint is applied; its condition before and after the restraint was imposed; the nature of the restraint and its effect, actual or probable." Board of Trade v. United States, 246 U.S. 231, 238 (1918). Thus, it is apparent that no simple formula exists for the determination of reasonableness. Certain kinds of restraints, however, have been declared by the courts to be per se unreasonable because experience has found then to produce undue competitive restrictions in the vast majority of cases. Price fixing arrangenents, both vertical and horizontal, are per se unreasonable, White Motor Co. v. United States, 372 U.S. 253 (1963) ; United States v. Socony Oil Corp., 310 U.S. 150 (1940). So are group boycotts, Fashion Originators' Guild, Inc. v. FTC, 312 U.S. 457 (1941), and market allocation agreements, White Motor Co. v. United States, supra at 259.

A good example of the difficulty of judging reasonableness is presented by the Court's gratuitous discussion of the reasonableness of the marketing hour restriction in Jezvel Tea. 381 U.S. at 693 n.6 There the Court examined all available ease law, both state and federal, with respect to the reasonableness of nuarketing hour restrictions but did not state its opirion as to the reasonableness of the restriction imposed by the union. The Court's discussion serves to illustrate that no reliable method exists by which the reasonableness of restrictions can be predicted which do not fall within one of the per se categories. 
confined to the issue of labor's exemption from the antitrust laws. However, non-exempt union conduct which unreasonably restrains product market competition will violate the antitrust laws. Whether a particular union activity unreasonably restrains product market competition should depend upon the facts of each case viewed in light of antitrust policy. Labor policy should play a minimal role in the analysis of substantive antitrust questions simce labor policies will already have been taken into account at the immunity level.

Daniel S. Frost 